\title{
Rural Grievances, Landholding Inequality and Civil Conflict
}

\author{
Henry Thomson*
}

February 29, 2016

\begin{abstract}
Economic grievances associated with landholding inequality play a central role in theories of political instability and civil conflict. However, cross-national empirical studies have failed to confirm a link between unequal distributions of land and civil war. This is due to problems in measuring and theorizing rural inequality. This paper makes a novel distinction between the effects of total landholding inequality and the concentration of land ownership on conflict. Total landholding inequality, which includes landlessness, captures economic grievances in the countryside and is positively associated with conflict. Gini coefficients of landholding concentration do not only capture grievances, but also landowners' ability to act collectively as rebels and a repressive rural elite. The relationship between landholding Ginis and conflict is shaped like an inverted ' $U$ ': inequality is associated with an increasing likelihood of conflict, but as concentration of landholdings reaches very high levels the likelihood of conflict decreases with the formation of a small repressive class of landowners. Results of cross-national regressions using new data on total land inequality and the concentration of landholdings confirm these predictions, providing novel evidence that landholding inequality is an important underlying cause of civil war.
\end{abstract}

*I would like to thank Ben Ansell, Marc Bellemare, Dan Berliner, Patrick M. Kuhn, Anna Ross, Henning Tamm, two reviwers and the editors for helpful comments. All remaining errors and omissions are my own. 
Grievances caused by economic inequality have long been thought to increase the risk of civil unrest and conflict (Russett 1964; Acemoglu and Robinson 2006). However, empirical evidence for the link between economic inequality and political instability is mixed (Fearon and Laitin 2003; Boix 2008; Houle 2009). In particular, results of cross-national quantitative studies have failed to establish a robust correlation between rural inequality, as measured by an unequal distribution of landholdings, and civil war (Muller et al. 1989; Collier and Hoeffler 2004). This is puzzling, considering that the rural population predominates in developing countries where civil war is most prevalent and ownership of land is the greatest single factor influencing rural households' social status and economic wellbeing, making an unequal distribution of land a major source of grievances and potential unrest.

In this research note, I argue that this null finding is due to problems in the conceptualization and measurement of rural inequality. Gini coefficients of landholding inequality only measure the distribution of land among landowners. They exclude the landless and, thus, overlook a large driver of economic grievances in the countryside. Moreover, the concentration of land ownership fails to capture the landowners' incentives to repress unrest and their ability to act collectively_-both as insurgents and as a repressive rural elite.

This research note addresses these problems both empirically and theoretically. Empirically, I introduce a new measure of landholding inequality. My measure accounts for the share of the rural population which does not own any land. Theoretically, the relationship between landholding Gini coefficients and conflict is shaped like an inverted ' $U$ ': inequality is associated with an increasing likelihood of conflict as both grievances and the ability of landowners to organize increase, but as concentration of landholdings and grievances reach very high levels the likelihood of conflict decreases with the formation of a cohesive and repressive rural elite.

I estimate cross-national regressions for over 100 states from 1948-1999 using new data on overall land inequality and concentration of landholdings. Their results confirm my 
theoretical predictions. Conflict onset is significantly correlated with higher levels of land inequality, when accounting for landlessness. There is a significant quadratic relationship between Gini coefficients of landholding concentration and conflict onset, with civil wars most likely to occur at moderately high levels of concentration of landholdings. The substantive size of these effects is large, with variation in the predicted probability of conflict onset across the range of both variables over half of that seen across observed values of GDP per capita, the most important predictor of civil war.

\section{Previous Literature: Economic Grievances, Landholding Inequal- ity and Civil Conflict}

Grievances caused by economic inequality play a central but controversial role in theories of political instability, from revolution and democratization to civil war. In relative deprivation theory, discrepancies between individuals' expected and achieved standards of living are an underlying cause of civil strife (Gurr 1968). Theories of democratization see income inequality as driving the economic incentives for poor citizens to seize power from the rich (Boix 2003; Acemoglu and Robinson 2006). Early studies of civil war emphasized the role played by inequality and economic grievances in conflict (Muller 1985; Midlarsky 1988). However, their role in democratization processes and civil war is contested. Boix (2003) argues for a link between income equality and democratization, but Houle (2009) disputes this finding and Ansell and Samuels (2014) find that the opposite relationship holds. Canonical studies by Collier and Hoeffler (2004) and Fearon and Laitin (2003) find no role for income inequality in explaining civil war onset. More recent work finds a significant role for horizontal, or inter-group, inequality in causing civil conflict (Ostby 2008; Cederman, Weidmann, and Gleditsch 2011; Bartusevicius 2014; Baten and Mumme 2013).

Rural inequality occupies a similarly central and contested role in the civil war literature. Both policymakers and scholars have argued that landholding inequality is a 
precondition for political instability and civil conflict. Convinced that landholding inequality was the underlying cause of communist insurgencies in Asia and social turmoil in Latin America, the United States government promoted land reform as a policy to forestall such instability in the 1950s and 1960s (Kapstein 2014). For many scholars, unequal distributions of land are the result of a deeper breakdown of traditional social structures which increases the risk of political instability. ${ }^{1}$ For Acemoglu and Robinson (2006) and Boix (2008), because land is highly amenable to taxation and redistribution, land inequality creates incentives for both revolt against landed elites and violent repression of such revolts.

However, despite these diverse perspectives positing a link between landholding inequality, economic grievances and civil conflict, cross-national empirical evidence of this link remains surprisingly elusive. Although early studies by Russett (1964) and Midlarsky (1988) found a positive correlation between inequality and conflict, these were rebutted by others which disputed the validity of the Gini coefficient as a measure of rural inequality and lamented the poor quality of cross-national data on the distribution of land ownership (Muller and Seligson 1987; Muller et al. 1989; Lichbach 1989). Variations of this debate have continued, with Binswanger, Deininger, and Feder (1995) finding that unequal patterns of land ownership have been a persistent source of civil strife; Collier and Hoeffler (2004) finding that landholding Gini coefficients are not correlated with conflict onset; and Brockett (1992) and Cramer (2003) arguing that although land inequality should be considered a prime cause of political violence, cross-national indicators such as Gini coefficients ignore social and historical contexts which really drive grievances and disputes. Boix $(2008,414)$ finds that landholding inequality is linked to civil war, but only under conditions of general asset specificity.

The lack of consistent results linking landholding inequality to civil conflict crossnationally appears still more surprising when one considers the central role which grievances around land play in single-case studies. Sansom linked the existence of a small landlord

\footnotetext{
${ }^{1}$ Russett (1964); Scott (1976); Midlarsky (1988); Brockett (1992). Rural poverty has also been argued to increase the likelihood of conflict. See, for example, Fjelde (2014) and von Uexkuell (2014).
} 
class alongside a large landless population to peasant support for insurgents in Vietnam (Sansom 1970, 228-245). Albertus, Brambor, and Ceneviva (2014) find that land invasions were associated with landholding inequality in Brazil, and Albertus and Kaplan (2013, fn.11) find that landholding inequality was correlated with guerilla activity in Colombian districts from 1988-2000. Gomes (2015) finds that land inequality was correlated with conflict onset and intensity in India from 1980-2010, Murshed and Gates (2005) find that landlessness was associated with more intense conflict during the Maoist insurgency in Nepal in the late 1990s, and Verwimp (2005) finds that land-poor peasants were significantly more likely to be perpetrate violence against landlords during the Rwandan genocide.

\section{Rural Inequality, Grievances, Collective Action and Civil Conflict}

The discrepancy between our theoretical expectations and results of single-country studies on the one hand, and cross-national empirical evidence for a link between landholding inequality and civil conflict on the other, is striking. I argue that it is due to problems with the measurement of rural inequality and an under-developed, one-dimensional account of its link with conflict. Rural inequality has effects on the likelihood of conflict through two causal pathways: economic grievances and collective action. Economic grievances are best captured by a measure of total landholding inequality which includes landlessness, while the propensity of the rural population for collective action is best captured by a Gini coefficient of landholding concentration.

Economic grievances engendered by inequality increase the likelihood of conflict in a linear fashion, increasing perceptions of relative deprivation, potential gains from redistribution and thus the potential payoff to violent rebellion. An unequal distribution of land is likely to be associated with acute perceptions of relative deprivation in the countryside, because the ownership of land is so closely tied to economic well-being and social status in rural communities. As Scott (1976) argues, landless wage workers and 
sharecroppers face a far more economically precarious existence than landowners. Wood (2003) describes the deep-seated resentments and loss of dignity which landholding inequality engenders in the countryside. Relatedly, for Acemoglu and Robinson (2006) and Boix (2003), inequality increases the payoff to rebellion and subsequent redistribution by the landless or land-poor, increasing the likelihood of conflict.

Relative deprivation and grievances have been linked to conflict primarily in cases of inter-group or horizontal inequality where economic divisions overlap with identity-based cleavages. ${ }^{2}$ Shared identities among the relatively deprived groups enhance cohesion and facilitate mobilization, while vertical inequality among individuals does not promote conflict in this way. More clearly than income inequality, rural inequality has a horizontal aspect, as it fosters resentment between relatively clearly divided groups: the land-poor and landless versus landlords; and rural residents versus the state (Scott 1976; Wood 2003). Because rents fall disproportionately on smallholders, who must rent land in order to meet subsistence requirements, and on the landless who must pay rent in order to produce at all, total landholding inequality fosters resentment against landlords who can demand payment or collateral for outstanding debts. Similarly, because taxes calculated per capita or per unit of produce fall disproportionately heavily on smallholders and the landless who exist only slightly above the poverty line, total landholding inequality fosters resentment against the state.

A Gini coefficient of concentration of land ownership does not capture economic inequality in the countryside because it only measures the distribution of land among landowners, ignoring the landless. A measure of total landholding inequality, which takes into account both landlessness and the concentration of land ownership, is a more accurate indicator of poverty, grievances and the propensity for violence among the rural population. I predict that total landholding inequality will be correlated with civil conflict onset:

- H1: Greater levels of total landholding inequality will be correlated with greater

\footnotetext{
${ }^{2}$ See, for example, Ostby (2008) and Cederman, Weidmann, and Gleditsch (2011).
} 
probabilities of conflict onset, ceteris paribus.

The propensity of the rural population for collective action is increasing in the concentration of land ownership but because this form of inequality has important consequences for the nature of the rural population it has a non-linear effect on the likelihood of conflict. As the concentration of landholdings increases, it emboldens independent farmers to mobilize in opposition to the state, increasing the likelihood of conflict. Very low land Ginis are associated with smallholder agriculture as seen in East Asia and parts of sub-saharan Africa. As famously argued by Scott (1985), and more recently by Kuhn and Weidmann (2015), such populations are extremely difficult to mobilize. However, as landholding concentration increases, these problems are mitigated. Greater concentrations of landholdings go hand in hand with a smaller number of landowners, each with a greater endowment of economic resources. This smaller, more cohesive group is more likely to be mobilized in collective action by entrepreneurs of violence, resulting in an increased likelihood of civil war (Olson 1965; Baland and Platteau 1997).

However, as concentrations of landholdings reach very high levels, as seen in Latin America and East Africa, the rural population is dominated by a landed elite with the incentives and ability to organize not in rebellion, but in repression, suppressing the likelihood of civil war. At very high levels of landholding concentration, the costs of repression are lower versus those of redistributive concessions and reforms. ${ }^{3}$ As the size of landholdings becomes very large, landowners face problems in preventing incursions onto their land and enforcing contracts with tenants. This causes them to invest increasingly in agents and watchmen who can be used as instruments of repression. ${ }^{4}$ The number of landowners is so small at very high levels of landholding inequality that they form a cohesive social group which finds it easy to solve the collective action problem, is

\footnotetext{
${ }^{3}$ Acemoglu and Robinson (2006). Albertus and Kaplan (2013) and Albertus, Brambor, and Ceneviva (2014) show that large landowners block land reform and suppress land invasions where possible.

${ }^{4}$ Albertus and Kaplan (2013), for example, find that land invasions are more likely to be repelled by landed elites under conditions of high landholding concentration. Baland and Robinson (2012) demonstrate that large landowners control workers' political and voting behavior. On the repressive capacity of landlords, see also Scott (1976) and Wood (2003).
} 
often politically influential at the national level and can mobilize the state's repressive and economic resources to their cause. ${ }^{5}$ The effect of landholding concentration on collective action leads to a turning point at high levels of landholding inequality, as large landowners have more to lose from concessions and find it easier to repress unrest. I therefore hypothesize a quadratic, inverted "U"-shaped relationship between concentration of landholdings and the onset of civil conflict.

- H2: Greater concentrations of landholdings, as measured by a Gini coefficient, will be significantly correlated with greater probabilities of conflict at moderate levels of landholding concentration, ceteris paribus.

\section{Data: Landholding Inequality and Concentration of Landholdings}

Like previous researchers, I am faced with a significant problem of data availability in estimating the relationship between rural inequality and civil conflict. However, the substantive and theoretical salience of the research question justify a considered, rigorous attempt to compile a dataset on land distributions at the country-year level, and analyze how these variables affect the likelihood of conflict. I collected a complete dataset of the best and most recent measures of landholding inequality and concentrations of landholdings from multiple sources. Both of the measures used are new to political science, are of better quality and coverage, and have more clearly specified theoretical links to conflict than variables used in earlier cross-national studies. However, problems with data availability remain. Measures of land distributions are collected only at ten-year intervals, at best, in national agricultural censuses coordinated by the FAO, and both my measures depend on these censuses for their underlying data. I therefore must interpolate the data

\footnotetext{
${ }^{5}$ See, for example, Moore's (1966) classic account of a repressive alliance between labor-intensive agriculture and the state. Wood (2003) describes a similar alliance between large El Salvadorian landowners and the military. Thomson (2015) shows that German landed elites effectively mobilized the state against Social Democrats in the nineteenth century, and Thomson (2016) finds that landed elites are able to extract rents from central government in the form of favorable agricultural policies.
} 
to create a country-year dataset suitable for analyzing civil conflict. ${ }^{6}$

The first independent variable included in my models is Land Ineq, a measure of total landholding inequality which combines landlessness with concentration of land ownership by Erickson and Vollrath (2004). ${ }^{7}$ This measure of total landholding inequality is the concentration of land ownership weighted by the national rate of landlessness. It is constructed

$$
\text { LandIneq }=1-2 B(H / P)
$$

where $B$ captures the equality of the land distribution, $H$ is the total number of landholdings in a country and $P$ is the total agricultural population in a country. It should be noted that this is not simply a Gini coefficient which extends the x-axis of the Lorenz curve by including the landless. Although it might seem that such an augmented Gini coefficient could be a preferable measure of total landholding inequality, it is not a viable or preferable measure for two reasons. First, landholding Ginis are calculated using the distribution of land across households, and because no data on the total number of rural households is available, the Lorenz curve cannot be simply extended to create an augmented Gini. Second, using the agricultural population per landholding gives a more complete sense of how many people work on a given plot of land, which could include many family members belonging to one household; a form of inequality which would not be picked up by the augmented Gini coefficient.

The variable capturing total land inequality, Land Ineq, is very low where both the concentration of land ownership and the population per landholding are low, for example in Finland, and high where this situation is reversed, for example in Argentina. Crucially, it is possible for a country to have a higher concentration of landownership than another country, but lower total landholding inequality. For example, Austria had a

\footnotetext{
${ }^{6}$ Interpolation is not an illegitimate inflation of the number of observations in my dataset, but an approximation of the true values of the land inequality variables as they change over time. Interpolation does bring a specific problem: It introduces an autoregressive component into the independent variable. I specify standard errors clustered by country, which remove the concern of autocorrelation in the interpolated inequality observations.

${ }^{7}$ I am grateful to Dietrich Vollrath for sharing these data.
} 
Gini of 0.66 in 1990, but due to its high 0.99 holdings per head of agricultural population its total landholding inequality was only 0.66. India in 1985, on the other hand, had a lower Gini of 0.59 but a large amount of landlessness, with only 0.44 land holdings per head of agricultural population, leading to a total landholding inequality level of 0.82 . The Land Ineq is an indicator of rural grievances, because it captures both the rate of landlessness and the concentration of landholdings, and should be linearly associated with civil conflict.

Because the construction of the Land Ineq variable requires data on the total number of landholdings and total agricultural population, as well as the landholding Gini coefficient, its coverage is not as complete as data measuring only the concentration of landholdings. The dataset includes a total of 214 observations for 99 states between 1958, before which no agricultural population data are available, and 1994. The data are, at best, at ten-year intervals, matching the dates of FAO agricultural censuses. Thus, the maximum number of observations per country in the dataset is four (OECD countries, Pakistan, India), most countries have two or three observations and 34 countries have only one observation. I perform a simple interpolation between observed values in order to create a country-year landholding inequality dataset. In the vast majority of cases, this entailed an interpolation between datapoints ten years apart (the interval of the official censuses), with only 8 cases interpolating over a twenty year interval. Because landholding inequality is a very slow-moving variable, interpolated values over a decade are a good indication of real land inequality in a country. ${ }^{8}$ The average level of landholding inequality in my models is 0.81 , with a range from 0.4 (Lesotho in 1970) to 0.98 (Hungary in 1980). I present summary statistics of all variables in Table 2, supplementary materials.

The second independent variable included in my models is Land Gini, a Gini coefficient of landholding concentration, along with its squared term Land Gini Sq. As

\footnotetext{
${ }^{8}$ In Brazil, for example, total landholding inequality changed only from 0.96 to 0.95 over the decade from 1960 to 1970; in India it moved from 0.87 to 0.85 over the same period while in Sierra Leone it increased from 0.80 to 0.88 from 1971 to 1985 . In countries which experienced significant land reform, the changes in total landholding inequality are mixed. In Japan, the change is from 0.75 in 1960 to 0.70 in 1970 and 0.64 in 1980. In South Korea, the change is only from 0.71 to 0.70 and then 0.75 over the same period.
} 
there is no single dataset which includes all available landholding Ginis, I compiled data from five sources to get the maximum possible coverage of 406 observations across 126 states between 1948 and $2003 .{ }^{9}$ Aside from very small differences due to rounding during calculations, the data are identical across sources when they overlap, because they are from the same underlying census results. As with the landholding inequality data, I linearly interpolate the data, resulting in a total of 2969 observations. ${ }^{10}$ The minimum level of landholding concentration was a Gini coefficient of 0.18 in Norway in 1999, and the maximum was 0.98 in Hungary in 1980. The two independent variables are illustrated by the scatterplot presented in Figure 1.

Correlation coefficients presented in Table 3, supplementary materials, show a weak positive correlation $(r=0.07)$ between total landholding inequality and conflict onset, and no correlation between land Ginis and conflict $(r=-0.01)$. The simple correlation between total landholding inequality and conflict is therefore of a similar magnitude to conflict's correlation with total population and GDP $(r=0.06$ and $r=-0.09$, respectively). Given that I theorize a quadratic relationship between Ginis of landholding concentration and conflict, the lack of a strong linear correlation is not surprising or damaging to the plausibility of my theory. Total landholding inequality and landholding concentration are correlated at $r=0.45$.

There are several potential concerns with my independent variables. First, as Figure 1 clearly shows, there is a strong clustering of countries with low landholding inequality and land Ginis in Western Europe, and of countries with high values on these variables in Latin America. Data on landholding concentration could therefore be collinear with factors such as culture or religion, by which certain groups are more tolerant of inequality than others. In addition, because developing countries have carried out less agricultural censuses, my

9 These sources are Deininger and Squire (1998), Erickson and Vollrath (2004), Frankema (2010), FAO (1997) and Jazairy, Alamgir, and Panuccio (1992).

10 The land Gini is even slower-moving than the total landholding inequality variable, as it captures only the distribution of land ownership, not shifts in population between rural and urban areas. The large shifts in total landholding inequality in Japan noted above, for example, are much more dramatic than the change in the land Gini which moved only from 0.41 to 0.38 from 1960 to 1990 . In Brazil, the land Gini also barely changed from 0.84 to 0.85 from 1960 to 1980. 
sample is skewed towards developed countries, compared to that in the F\&L models. To account for these problems, I also estimated my main models including regional dummy variables, and results are substantively identical to those presented below. Second, I have a significant problem with missing data, particularly for my Land Ineq variable. The Land Ineq variable only covers $43 \%$ of the observations covered by the Land Gini data, though this missingness is equally distributed across regions and time. I therefore estimate a model for this variable via multiple imputation. Finally, some readers might be concerned about potential reverse causality in the independent variables, by which the distribution of land is dependent on the risk of civil conflict as governments undertake land reform to pre-empt grievances caused by inequality. This concern can be mitigated by the observation that levels of landholding inequality are primarily determined by exogenous factors such as geography, historical land-use patterns and political institutions, and change very slowly over time even in the face of significant land reform (Erickson and Vollrath 2004; Frankema 2010).

My primary analyses take two indicators of civil war onset from Fearon and Laitin (2003, elsewhere F\&L) and Collier and Hoeffler (2004, elsewhere C\&H), respectively, as their dependent variables. The former dataset defines a civil war as fighting between agents of a state and organized nonstate groups which killed at least 10,000 in total, 100 per year on average, and at least 100 on each side. This dataset includes 1180 observations which overlap with the Land Ineq variable, including 17 cases of civil war onset; 2749 observations overlap with the Land Gini data, including 34 cases of civil war onset. The second dataset defines a civil war as an internal conflict between government forces and organized rebel groups with at least 1,000 battle deaths per year, and in which at least $5 \%$ of total deaths are suffered by each side. This dataset includes 1174 observations which overlap with the Land Ineq variable, including 13 cases of civil war onset; 2709 observations overlap with the Land Gini data, including 23 cases of civil war onset. ${ }^{11}$

\footnotetext{
11 The F\&L dataset includes a total of 110 cases of civil war in 6610 country-year observations; my models of total landholding inequality include around $20 \%$ of the total observations and the same proportion of conflict onset; the land Gini models include $43 \%$ of total observations and $32 \%$ of the conflicts. The country-years included in my models are widely distributed across regions; for a list, see
} 
The two indicators of civil war onset are correlated at 0.45 . In robustness tests, I exclude country-years from my analyses in which a previous conflict was ongoing, in order to mitigate any bias originating from equating years without new conflict with years with no conflict. I also estimate models of conflict incidence using the intra-state conflict dataset by Gleditsch et al. (2002).

Figure 1: Civil Wars, Average Landholding Inequality and Land Gini

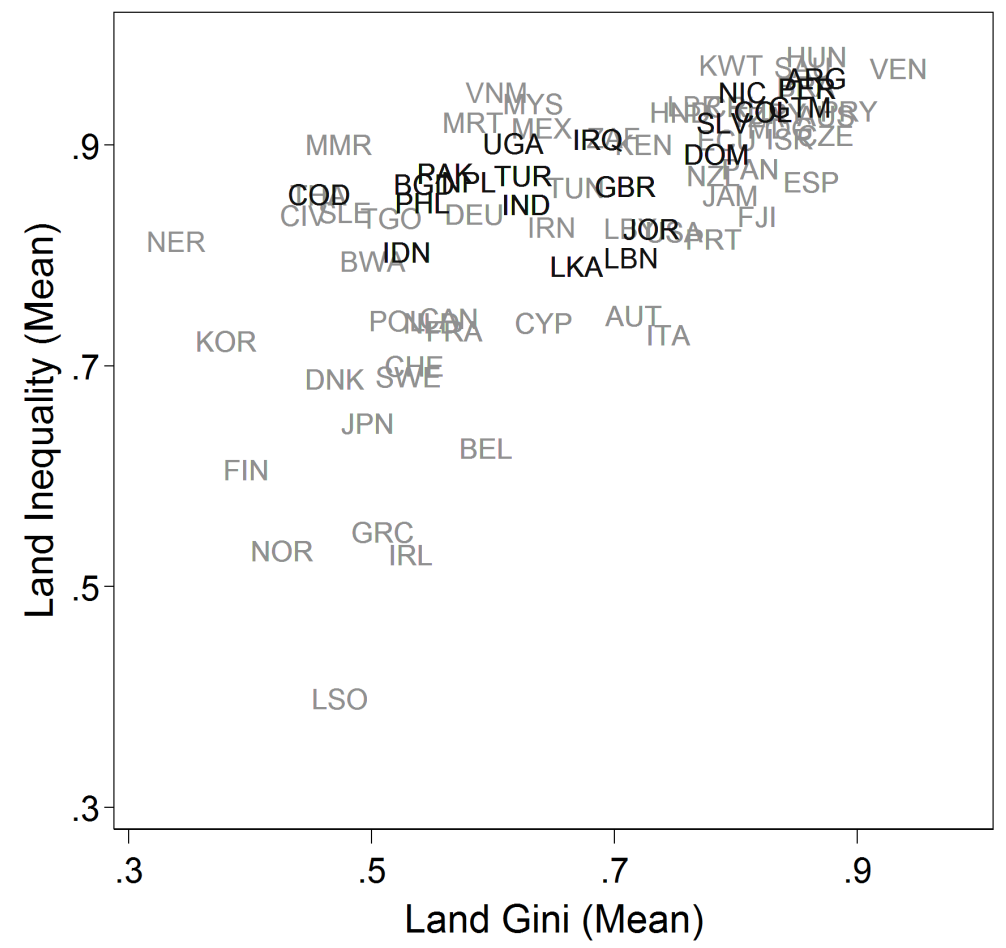

Note: Land Inequality and Land Gini values are country averages of all observations used in Model 3, Table 1. Country names shaded in black experienced civil war during period they were included in the same model.

In Figure 1, I present a scatter-plot of each country's average Land Gini and Land Ineq variables, plotted on the $\mathrm{x}$ and $\mathrm{y}$ axis respectively. Using abbreviated country names as markers, I shade them dark black if the country experienced a civil war onset in the years included in my land Gini model using the F\&L dataset; if they did not supplementary materials. The F\&L civil wars which are included in the land Gini models are: Dominican Republic (1965), Guatemala (1968), El Salvador (1979), Nicaragua (1978, 1981), Colombia (1963), Peru (1981) Argentina (1973), UK (1969), Senegal (1989), Democratic Republic of Congo (1977), Uganda (1981), Turkey (1977, 1984), Iraq (1959, 1961), Lebanon (1975), Jordan (1970), India (1982, 1989), Pakistan (1971, 1973, 1993), Bangladesh (1976), Sri Lanka (1971, 1983, 1987), Nepal (1997), Philippines (1968, 1972), Indonesia (1965, 1975, 1991). See also Figure 1. 
experience a civil war the country name is in gray. This graph is a first plausibility test of my argument, and is broadly supportive. No country with levels of total landholding inequality below 0.79 experienced civil war onset; this was the level of inequality in Sri Lanka in 1971 and is slightly below the mean for all observations in the dataset. Civil war onset is observed at higher levels of total landholding inequality, from Democratic Republic of Congo through Pakistan, Iraq and Latin America. States with a wider range of landholding concentration Ginis experienced civil war. Conflict is rare among countries with very low land Ginis, but at moderate levels between 0.50 and 0.70 several states such as Indonesia, Uganda and Lebanon experienced conflict.

I follow F\&L, and include several control variables in all my models (which are not all reported in the results table). I include lagged indicators of GDP per capita, the natural log of the country's population, instability and the Polity score; the log of the percentage of each country which is mountainous, an indicator of noncontiguous and oil exporting states, and measures of religious and ethnic fractionalization. In order to control for time dependence, I include a lagged dependent variable in my models of the F\&L conflict indicator. Because a lagged onset variable by $\mathrm{C} \& \mathrm{H}$ perfectly predicts civil war in the sample of countries for which I have land inequality data, I instead use years since the last civil war onset and three cubic splines to control for time dependence in these models, following Beck, Katz, and Tucker (1998). I also estimate my models of the F\&L data using these controls in a second set of analyses. In models testing the predictions of Boix's (2008) theory I use data on the proportion of the population working in the agricultural sector; these are published by the statistics division of the Food and Agricultural Organization of the United Nations (FAO).

\section{Estimation and Results}

My empirical analysis proceeds from a set of basic models augmenting those by Fearon and Laitin to more elaborate tests of alternative arguments, specifications of the dependent 
variable, controls for time dependence and attempts to deal with the problem of missing data. In my initial analysis, I estimate two sets of logistic regression models, one set for each indicator of civil war onset. The first model estimates the effect of total landholding inequality, including landlessness, on conflict onset,

$$
\ln \left(\frac{\operatorname{Pr}\left(y_{i, t}\right)}{1-\operatorname{Pr}\left(y_{i, t}\right)}\right)=\beta_{1}+\beta_{2} \text { LandIneq }_{i, t}+\beta_{3} \mathbf{X}_{i, t}+\epsilon_{i, t},
$$

where $\operatorname{Pr}\left(y_{i, t}\right)$ is the probability of conflict onset in a given country-year, LandIneq $\mathbf{q}_{i, t}$ is a vector of land inequality values by country-year, $\mathbf{X}_{i, t}$ is a vector of control variables outlined above, and $\epsilon_{i, t}$ is a vector of error terms, which I specify to be clustered by country, to account for serial correlation in the interpolated rural inequality data. The results of these models are reported as Models 1 and 2 in Table 1. The second model estimates the effect of landholding conentration on conflict onset,

$$
\ln \left(\frac{\operatorname{Pr}\left(y_{i, t}\right)}{1-\operatorname{Pr}\left(y_{i, t}\right)}\right)=\beta_{1}+\beta_{2} \text { LandGini }_{i, t}+\beta_{3} \text { LandGiniSq }_{i, t}+\beta_{4} \mathbf{X}_{i, t}+\epsilon_{i, t},
$$

an identical equation except that it includes a vector of landholding Gini coefficients and its squared term in place of the total landholding inequality variable. The results of these models are reported as Models 3 and 4 in Table 1 . The third model estimates the effects of both total landholding inequality and landholding concentration on conflict onset,

$\ln \left(\frac{\operatorname{Pr}\left(y_{i, t}\right)}{1-\operatorname{Pr}\left(y_{i, t}\right)}\right)=\beta_{1}+\beta_{2}$ LandIneq $_{i, t}+$ LandGini $_{i, t}+\beta_{3}$ LandGiniSq $_{i, t}+\beta_{4} \mathbf{X}_{i, t}+\epsilon_{i, t}$ and the results of these models are reported as Models 5 and 6 in Table 1. Because the variable Land Ineq is constructed as the variable Land Gini weighted by landlessness, the results of models including both variables must be interpreted carefully. The coefficient on the Land Ineq variable in these models is the effect of landlessness, holding the concentration of landholding concentration, as measured by Land Gini, constant. It 
therefore has a slightly different interpretation to that of the coefficient on Land Ineq when included on its own, though my theoretical prediction is still for a linear positive association with conflict onset. Because of this subtlety in interpretation, I focus discussion of results on the first two sets of models, and only plot predicted probabilities of models including the each variable on its own in Figures 2 and 3. 


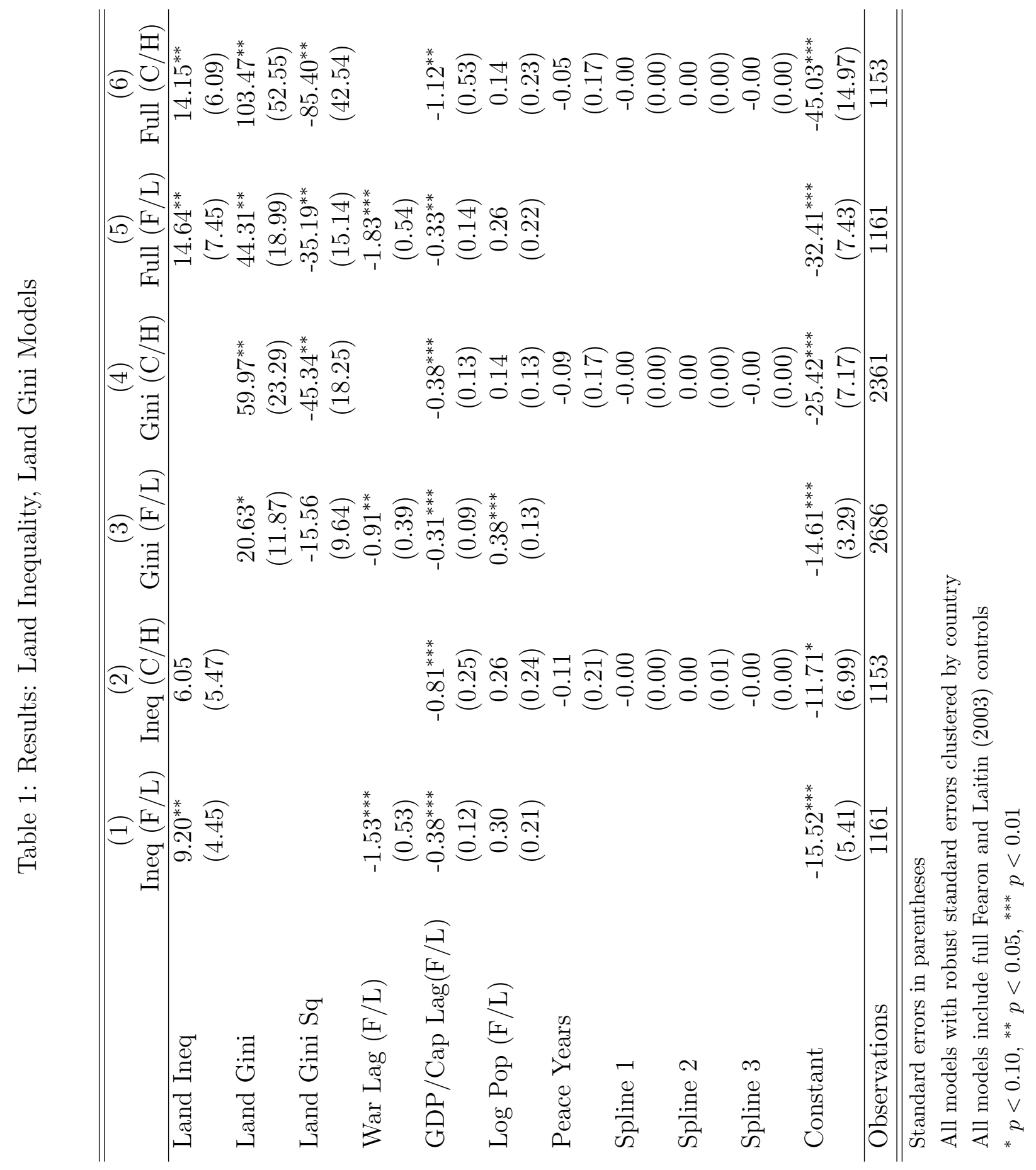


Turning first to the models of the effects of total landholding inequality on conflict onset, both Models 1 and 2 indicate the hypothesized positive, monotonic relationship. In Model 1, taking the L\&F conflict data as its dependent variable, this relationship is statistically significant at the $p<0.05$ level, while in Model 2, of the C\&H data, the coefficient is positive but not significant at the $p<0.10$ level. Because these coefficients are only estimates of the average marginal effect of landholding inequality on the likelihood of conflict onset, I calculated predicted probabilities across the range of the variable and plot them, along with $95 \%$ confidence intervals, in Figure $2 .{ }^{12}$ Here, we see that the likelihood of conflict onset is increasing in landholding inequality, but that the relationship is only statistically significant at relatively high levels of landholding inequality above 0.75 in Model 1 and 0.80 in Model 2. The uncertainty around the probability estimates increases at very high levels of landholding inequality, above 0.95 , where the relationship is only barely significant at the $p<0.95$ level in Model 2. However, the substantive effects of total landholding inequality on conflict onset, holding all else equal, are large in both models. The probability of civil war onset increases from zero to 0.035 across the range of the landholding inequality variable in the L\&F model and from zero to 0.021 in the model of the $\mathrm{C} \& \mathrm{H}$ onset indicator. For comparison, the variation in the predicted probability of conflict onset across the range of the logged GDP per capita variable in the L\&F model is from 0.05 to zero as GDP increases.

Models 3 and 4 in Table 1 estimate the effect of landholding concentration on civil war onset, using the $\mathrm{F} \& \mathrm{~L}$ and $\mathrm{C} \& \mathrm{H}$ indicators, respectively. Both models confirm the hypothesized quadratic relationship between Gini coefficients of the concentration of landholdings and conflict onset, with coefficient on the Land Gini variable positive and that on its squared term Land Gini Sq negative. The coefficients on each term are not statistically significant at the $p<0.05$ level in Model 3 but are significant at the $p<0.01$ level in Model 4. Joint tests of both coefficients are insignificant in Model 3 but significant at the $p<0.05$ level in Model 4. These being average effects, I plot predicted probabilities

\footnotetext{
12 All post-estimation analysis was carried out using the margins package in Stata.
} 
Figure 2: Results of Models 1 \& 2: Landholding Inequality and Conflict Onset
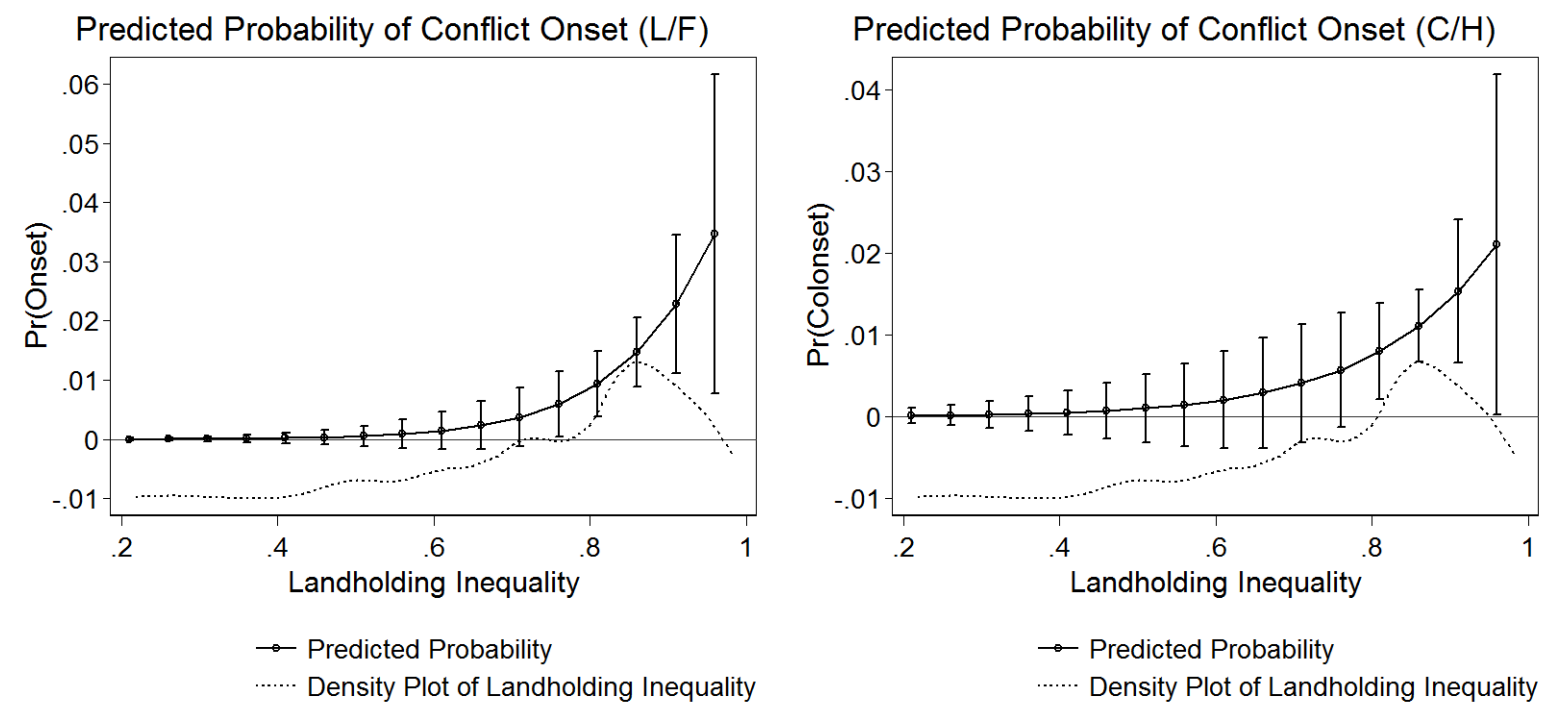

and their 95\% confidence intervals in Figure 3. Examination of the predicted probabilities indicates that the likelihood of civil conflict onset increases to become significantly greater than zero at moderate levels of landholding concentration, with Gini coefficients of between 0.38 and 0.83 in Model 3 and between 0.48 and 0.78 in Model 4 . The likelihood of civil conflict, holding all else equal, peaks at a Gini of 0.68 in both models, with a predicted probability of 0.017 in Model 3 and 0.021 in Model 4. These are smaller substantive effects than those of total landholding inequality, and less than half the size of the total effect of GDP on conflict onset, but they are statistically significant. At very high levels of landholding concentration, the likelihood of civil conflict declines in both models, although this decline is estimated with much more precision in Model 4. The decline in the probability of conflict as land Ginis increase from 0.68 to their maximum levels of 0.98 is not significant at the $p<0.10$ level in Model 3, but significant at the $p<0.05$ level in Model 4 .

In Models 5 and 6 in Table 1, I estimate the effects of total landholding inequality alongside those of landholding concentration. Because total landholding inequality is partially a function of the land Gini, these models should be interpreted as comparing the effects of landlessness - that is, the variation in Land Ineq which is not perfectly 
Figure 3: Results of Models 3 \& 4: Land Gini and Conflict Onset
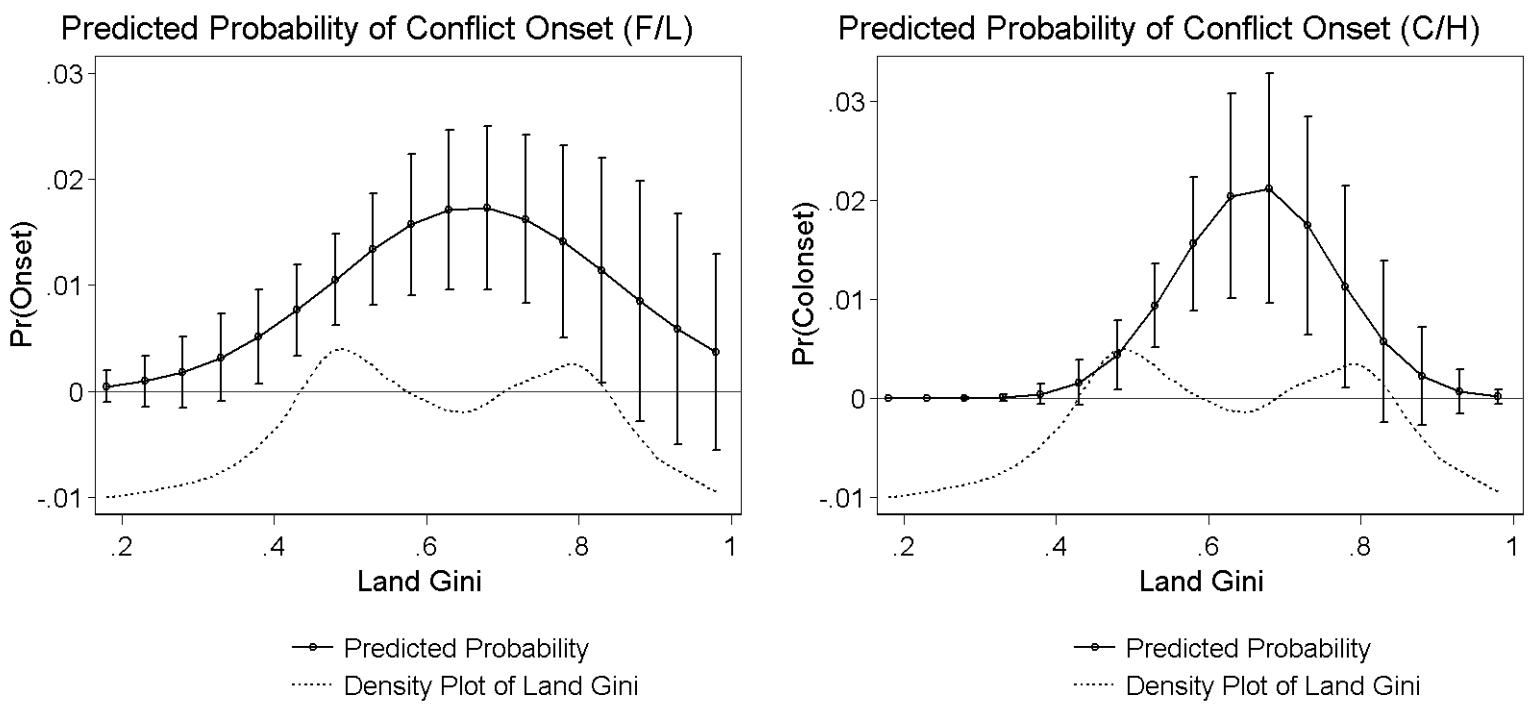

correlated with Land Gini- on civil war, versus the effects of landholding concentration. In both models, the signs of all variables remain the same as when they were included on their own, and all coefficients in these models are significant at the $p<0.05$ level. Interestingly, the magnitude of the effects of these variables are also greater in these full models. The probability of conflict onset increases from zero to 0.054 (versus 0.035 ) across the range of the landholding inequality variable in the L\&F model, and the probability of conflict onset peaks at 0.032 (versus 0.017 ) in the land Gini model.

Overall, the results presented in Table 1 confirm my theoretical predictions and are an important amendment to previous findings on the relationship between economic grievances and civil war. Far from being irrelevant for the onset of civil conflict, rural grievances which are caused by total landholding inequality have statistically and substantively significant effects on conflict onset, increasing the likelihood of conflict in a given country-year by at least two percentage points, holding all else constant. Similarly, the concentration of land ownership has significant positive effects on the likelihood of civil conflict at moderate levels between 0.45 and 0.75 , increasing the probability of conflict onset by as much as two percentage points, holding all else constant.

In models reported and more fully discussed in the supplementary materials, I go on 
to test alternative arguments on the relationship between rural inequality and conflict, and the robustness of my initial results. I find no quadratic relationship between total landholding inequality and conflict. I also test for a simple linear relationship between Gini coefficients of landholding concentration and conflict. Similarly to previous studies, I find no significant correlation between the two variables after controlling for relevant confounding factors. I test and find little support for Boix's (2008) theory, which asserts that landholding inequality's effects on civil conflict are conditional on total asset specificity. Results of models which include alternative controls for time dependence and alternative specifications of the dependent variable are broadly similar to those in Table 1. I also estimate a model replicating Model 1 in Table 1 via multiple imputation. In this model, increases in total landholding inequality across its range are associated with increases in the probability of conflict onset very similar to those seen in the model presented in Table 1. However, these increases are not statistically significant at the $p<0.10$ level.

\section{Conclusion}

In this research note, I argued that previous studies did not find a link between rural inequality and civil conflict because they did not consider the landless rural population and misunderstood the link between concentration of land ownership and conflict. I showed that measures of landholding inequality which included the landless are in fact significantly correlated with civil war onset, and that the relationship between landholding Gini coefficients and conflict onset is shaped like an inverted "U", with conflict most likely at moderate levels of concentration. This contribution is significant. It gives crossnational empirical support to the long-posited link between rural inequality and civil war. It also contributes to the debate around economic inequality, grievances and their contribution to political instability. Economic grievances in the countryside should not be ruled out as important underlying causes of civil war.

Demonstrating a link between landholding inequality and civil conflict opens up sev- 
eral avenues for future research. Findings on the effects of global agricultural price shocks on civil conflict could look at how the effects of these price shocks are distributed across the rural population and their effects on conflict are conditional on inequality. More empirical research is needed to fully explain the decrease in the probability of conflict onset at very high levels of landholding concentration, and demonstrate the mechanism of repression by landed elites. Finally, given pervasive interventions of governments in agricultural markets across the world, it remains to be seen how both global price shocks and economic grievances in the countryside are mitigated by agricultural policies which distort rural incomes, and how these policies have effects on civil war. 


\section{Bibliography}

Acemoglu, Daron and James Robinson. 2006. Economic Origins of Democracy and Dictatorship. New York: Cambridge University Press.

Albertus, Michael, Thomas Brambor, and Ricardo Ceneviva. 2014. "Land Inequality and Rural Unrest: Theory and Evidence from Brazil." Working paper. URL http: //ssrn. com/abstract=2442943.

Albertus, Michael and Oliver Kaplan. 2013. "Land Reform as a Counterinsurgency Policy: Evidence from Colombia." Journal of Conflict Resolution 57 (2):198-231.

Ansell, Ben W. and David J. Samuels. 2014. Inequality and Democratization: An EliteCompetition Approach. New York: Cambridge University Press.

Baland, Jean-Marie and Jean-Philippe Platteau. 1997. "Wealth Inequality and Efficiency in the Commons. Part I: The Unregulated Case." Oxford Economic Papers 49 (4):451482.

Baland, Jean-Marie and James Robinson. 2012. "The Political Value of Land: Political Reform and Land Prices in Chile." American Journal of Political Science 56 (3):601619.

Bartusevicius, Henrikas. 2014. "The Inequality-Conflict Nexus Re-Examined: Income, Education and Popular Rebellions." Journal of Peace Research 51 (1):35-50.

Baten, Joerg and Christina Mumme. 2013. "Does Inequality Lead to Civil Wars? A Global Long-term Study Using Anthropometric Indicators (1816-1999)." European Journal of Political Economy 32:56-79.

Beck, Nathaniel, Jonathan N. Katz, and Richard Tucker. 1998. "Taking Time Seriously: Time-Series-Cross-Section Analysis with a Binary Dependent Variable." American Journal of Political Science 42 (4):1260-1288.

Behrman, J. and T.N. Srinivasan, editors. 1995. Handbook of Development Economics. Amsterdam: Elsevier.

Binswanger, Hans P., Klaus Deininger, and Gershon Feder. 1995. Power, Distortions, Revolt and Reform in Agricultural Land Relations, chap. 42. Vol. III of Behrman and Srinivasan (1995), 2659-2772.

Boix, Carles. 2003. Democracy and Redistribution. New York: Cambridge University Press.

2008. "Economic Roots of Civil Wars and Revolutions in the Contemporary World." World Politics 60 (3):390-437.

Brockett, Charles D. 1992. "Measuring Political Violence and Land Inequality in Central America." American Political Science Review 86 (1):169-176. 
Cederman, Lars-Erik, Nils B. Weidmann, and Kristian Skrede Gleditsch. 2011. "Horizontal Inequalities and Ethnonationalist Civil War: A Global Comparison." American Political Science Review 105 (3):478-495.

Collier, Paul and Anke Hoeffler. 2004. "Greed and Grievance in Civil War." Oxford Economic Papers 56 (4):563-595.

Cramer, Christopher. 2003. "Does Inequality Cause Civil Conflict?" Journal of International Development 15 (4):397-412.

Deininger, Klaus and Lyn Squire. 1998. "New Ways of Looking At Old Issues: Inequality and Growth." Journal of Development Economics 57 (2):259-287.

Erickson, Lennart and Dietrich Vollrath. 2004. "Dimensions of Land Inequality and Economic Development." IMF Working Paper. Number WP/04/158.

Fearon, James D. and David D. Laitin. 2003. "Ethnicity, Insurgency and Civil War." American Political Science Review 97 (1):75-90.

Fjelde, Hanne. 2014. "Farming or Fighting? Agricultural Price Shocks and Civil War in Africa." World Development 67:525-534.

Food and Agriculture Organization of the United Nations. 1997. Report on the 1990 World Census of Agriculture. Rome: FAO.

Frankema, Ewout. 2010. "The Colonial Roots of Land Inequality: Geography, Factor Endowments, or Institutions?" The Economic History Review 63 (2):418-451.

Gleditsch, Nils Petter, Peter Wallensteen, Mikael Eriksson, Margareta Sollenberg, and Havard Strand. 2002. "Armed Conflict 2001-1946: A New Dataset." Journal of Peace Research 39 (5):615-637.

Gomes, Joseph Flavian. 2015. "The Political Economy of the Maoist Conflict in India: An Empirical Analysis." World Development 68:96-123.

Gurr, Ted Robert. 1968. "A Causal Model of Civil Strife: A Comparative Analysis Using New Indices." American Political Science Review 62 (4):1104-1124.

Honaker, James, Gary King, and Matthew Blackwell. 2010. "Amelia II: A Program for Missing Data." URL http://gking.harvard.edu/amelia.

Houle, Christian. 2009. "Inequality and Democracy: Why Inequality Harms Consolidation but Does Not Affect Democratization." World Politics 61 (4):589-622.

Jazairy, Idriss, Mohiuddin Alamgir, and Theresa Panuccio. 1992. The State of World Poverty. London: International Fund for Agricultural Development.

Kapstein, Ethan B. 2014. "Land and Rebellion: Lessons for Counter-insurgency." Survival: Global Politics and Strategy 56 (2):109-128. 
Kuhn, Patrick M. and Nils B. Weidmann. 2015. "Unequal We Fight: Between- and Within-Group Inequality and Ethnic Civil War." Political Science Research and Methods 3 (3):543-568.

Lichbach, Mark Irving. 1989. "An Evaluation of "Does Economic Inequality Breed Political Conflict?" Studies." World Politics 41 (4):431-470.

Midlarsky, Manus I. 1988. "Rulers and the Ruled: Patterned Inequality and the Onset of Mass Political Violence." American Political Science Review 82 (2):491-509.

Moore, Barrington. 1966. Social Origins of Dictatorship and Democracy: Lord and Peasant in the Making of the Modern World. Boston: Beacon Press.

Muller, Edward N. 1985. "Income Inequality, Regime Repressiveness, and Political Violence." American Sociological Review 50 (1):47-61.

Muller, Edward N. and Mitchell A. Seligson. 1987. "Inequality and Insurgency." American Political Science Review 81 (2):425-452.

Muller, Edward N., Mitchell A. Seligson, Hung der Fu, and Manus I. Midlarsky. 1989. "Land Inequality and Political Violence." American Political Science Review $83(2): 577-596$.

Murshed, S. Mansoob and Scott Gates. 2005. "Spatial Horizontal Inequality and the Maoist Insurgency in Nepal." Review of Development Economics 9 (1):121-134.

Olson, Mancur. 1965. The Logic of Collective Action: Public Goods and the Theory of Groups. Cambridge, MA: Harvard University Press.

Ostby, Gudrun. 2008. "Polarization, Horizontal Inequalities and Violent Civil Conflict." Journal of Peace Research 45 (2):143-162.

Russett, Bruce M. 1964. "Inequality and Instability: The Relation of Land Tenure to Politics." World Politics 16 (3):442-454.

Sansom, Robert L. 1970. The Economics of Insurgency in the Mekong Delta of Vietnam. Cambridge, MA: MIT Press.

Scott, James C. 1976. The Moral Economy of the Peasant: Rebellion and Subsistence in Southeast Asia. New Haven: Yale University Press.

. 1985. Weapons of the Weak: Everyday Forms of Peasant Resistance. New Haven: Yale University Press.

Thomson, Henry. 2015. "Landholding Inequality, Political Strategy and Authoritarian Repression: Structure and Agency in Bismarck's 'Second Founding' of the German Empire." Studies in Comparative International Development 50 (1):73-97.

. 2016. "Food and Power: Agricultural Policy Under Democracy and Dictatorship." Comparative Politics URL http://ssrn.com/abstract=2597852. Forthcoming. 
Tomz, Michael, Jason Wittenberg, and Gary King. 2005. "Clarify: Software for Interpreting and Presenting Statistical Results." URL http://gking.harvard.edu.

Verwimp, Philip. 2005. "An Economic Profile of Peasant Perpetrators of Genocide: Micro-Level Evidence from Rwanda." Journal of Development Economics 77 (2):297323.

von Uexkuell, Nina. 2014. "Sustained drought, vulnerability and civil conflict in SubSaharan Africa." Political Geography 43:16-26.

Wood, Elisabeth Jean. 2003. Insurgent Collective Action and Civil War in El Salvador. New York: Cambridge University Press. 


\section{Supplementary Materials}

Table 2: Summary statistics

\begin{tabular}{lccccc}
\hline \hline \multicolumn{1}{c}{ Variable } & Mean & Std. Dev. & Min. & Max. & N \\
\hline Onset (F/L) & 0.01 & 0.11 & 0 & 1 & 2709 \\
Onset (C/H) & 0.01 & 0.1 & 0 & 1 & 2384 \\
Land Ineq & 0.81 & 0.12 & 0.4 & 0.98 & 1174 \\
Land Ineq Sq & 0.66 & 0.19 & 0.16 & 0.97 & 1174 \\
Land Gini & 0.63 & 0.16 & 0.18 & 0.98 & 2709 \\
Land Gini Sq & 0.42 & 0.2 & 0.03 & 0.96 & 2709 \\
War Lag (F/L) & 0.14 & 0.35 & 0 & 1 & 2709 \\
GDP/Cap Lag(F/L) & 4.58 & 4.19 & 0.27 & 41.02 & 2709 \\
Log Pop (F/L) & 9.37 & 1.41 & 6.27 & 14.01 & 2709 \\
\hline
\end{tabular}

Table 3: Correlation Table

\begin{tabular}{lcccc}
\hline \hline \multicolumn{1}{c}{ Variables } & Onset $(\mathrm{F} / \mathrm{L})$ & Onset $(\mathrm{C} / \mathrm{H})$ & Land Ineq & Land Gini \\
\hline Onset $(\mathrm{F} / \mathrm{L})$ & 1.00 & & & \\
Onset $(\mathrm{C} / \mathrm{H})$ & 0.45 & 1.00 & & \\
Land Ineq & 0.07 & 0.06 & 1.00 & \\
Land Gini & -0.01 & 0.01 & 0.67 & 1.00 \\
\hline \hline
\end{tabular}

\section{Discussion of Robustness Tests}

I now go on to test alternative arguments on the relationship between rural inequality and conflict, and the robustness of my initial results. These models are consistent with my theoretical predictions and support my argument on the distinction between total landholding inequality and Ginis of landholding concentration. In Model 1, Table 4, I test for a quadratic relationship between total landholding inequality and conflict. There is no significant decline in the likelihood of conflict at very high levels of this variable, with predicted probabilities only dropping very slightly from 0.026 to 0.022 as land inequality increases from 0.91 to 0.96 , its maximum. Consistent with my theoretical predictions, this result indicates that it is solely the concentration of landholdings which can lead to conflict being suppressed at very high levels. The high levels of landlessness which are entailed in very high total landholding inequality entail grievances which eliminate this negative effect on conflict onset. In Model 2, I test for a simple linear relationship between Gini coefficients of landholding concentration and conflict. Similarly to previous studies, I find no significant correlation between the two variables after controlling for relevant confounding factors. The predicted probability of conflict onset increases by less than one percentage point across the range of the variable. This result is in line with my theoretical predictions and the descriptive evidence presented in Figure 1. Civil war onset is most likely at moderate levels of landholding concentration, and similarly unlikely at both very low and very high levels of landholding concentration. 
In Models 3 and 4 in Table 4, I test Boix's theory, which asserts that landholding inequality's effects on civil conflict are conditional on total asset specificity, and predicts that the likelihood of conflict onset is greatest when landholding inequality is high and urbanization is low (Boix 2008). This is a genuinely new test of his argument, because he uses a measure of the proportion of family farms rather than inequality measures based on the distribution of landholdings in his analysis. Instead of his measure of urbanization, I include its inverse, the proportion of the population which is employed in the agricultural sector using data from the FAO, and interact this variable with Land Ineq in Model 3 and with Land Gini in Model 4. The results of these models provide little support for Boix's theory, and show a lack of robust results when compared to my models above. Although the signs on both the landholding inequality variables and rural population are positive, the sign of the coefficient on their interaction is negative, whereas Boix's model predicts a significant positive coefficient on this term. However, all coefficients are estimated with very high uncertainty, with the size of the standard errors far exceeding the size of the coefficients on the interaction terms, so I cannot draw any definitive conclusions from these models for his approach.

Model 5 in Table 4 replicates Model 5 in Table 1, taking the F\&L conflict indicator as its dependent variable, but it includes peace years and three time trends instead of a lagged dependent variable to control for time dependence. In this model, the signs and size of the coefficients on land inequality and the land Gini are very similar to their equivalents using a lagged dependent variable, and though the estimates are less precise examination of marginal effects gives substantive results very similar to models presented in Table 1. Total land inequality has positive effects on conflict onset which are significant at the $p<0.05$ level when this measure exceeds 0.76. Land Ginis have significant positive effects on conflict onset at levels between 0.43 and 0.83 .

In Table 5 I examine the effects of my independent variables of interest on alternative specifications of the dependent variable. Firstly, in Models 1 and 2 I use the F\&L conflict onset data, but I exclude from the analysis all country-years during which a civil war is ongoing and there is no new conflict onset. I do this to eliminate the potential bias which results from equating years in which there is no new conflict, but an ongoing civil war in a country, with years in which there is no conflict at all. This requires dropping a total of 807 observations from the dataset. Model 1 in Table 5 shows that the positive effect of total landholding inequality on conflict onset is unchanged by excluding these observations, with the sign and significance of the coefficient on the variable very similar to the results presented in Table 1, and significant effects seen at levels of inequality above 0.75. The results of Model 2 also show a similar quadratic relationship between Ginis of landholding concentration and conflict onset, with the probability of conflict peaking at a Gini of 0.68 .

In Models 3 and 4 in Table 5, I use a variable on conflict incidence from the Onset of Intrastate Armed Conflict dataset by Gleditsch et al. to model the effects of land inequality on the incidence of conflict (Gleditsch et al. 2002). I do this to, firstly, bolster confidence in my results by using a third source of data on civil war and, secondly, to look at conflict incidence rather than the onset of new conflicts. In Model 3, there is a significant positive correlation between total landholding inequality and the incidence of conflict, with conflict significantly more likely at levels of inequality above 0.66 . This suggests a similar effect of rural grievances on both conflict onset and the likelihood of 
subsequent conflict incidence. Model 4 finds a quadratic relationship between Ginis of landholding concentration and conflict incidence, although the coefficient estimates are not as precise as those of models in Table 1, and in particular the decline in the likelihood of incidence at very high levels of landholding concentration is not as pronounced. This result provides interesting evidence on my argument emphasizing the ability of landed elites to repress conflict. The lack of a significant decline in conflict incidence at very high levels of landholding concentration suggests that once a conflict has started, a landed elite finds it more difficult to stop it than it does suppressing nascent unrest.

Because the high number of missing observations in my dataset on total landholding inequality - which contains a total of only 1174 observations compared to 2709 Gini coefficients - could induce bias in my results, I present a model replicating Model 1 in Table 1 estimated via multiple imputation as Model 5 in Table $5 .{ }^{13}$ This model is a test for whether the sample of country-years included in my landholding inequality dataset is driving my results linking this variable to conflict onset. The results are, given the high levels of missingness in the original data, a weak confirmation of the hypothesis that total landholding inequality is positively associated with conflict. The coefficient on the variable in Model 5 is positive, but not statistically significant -its $p$-value is 0.13 . Increases in total landholding inequality across its range are associated with a two percentage point increases in the probability of conflict onset, changes very similar in magnitude to those seen in the model presented in Table 1. However, these increases are not statistically significant at the $p<0.10$ level.

\footnotetext{
13 The imputation process was carried out using Amelia II by Honaker, King, and Blackwell (2010). I use five imputed datasets, and the imputation model includes all observations in the F\&L dataset. I include all independent variables in the imputation models as well as lags for land inequality and land Ginis. The analysis of the imputed datasets and subsequent calculations of predicted probabilities are done using the estsimp and simqi commands in the Clarify package by Tomz, Wittenberg, and King (2005).
} 


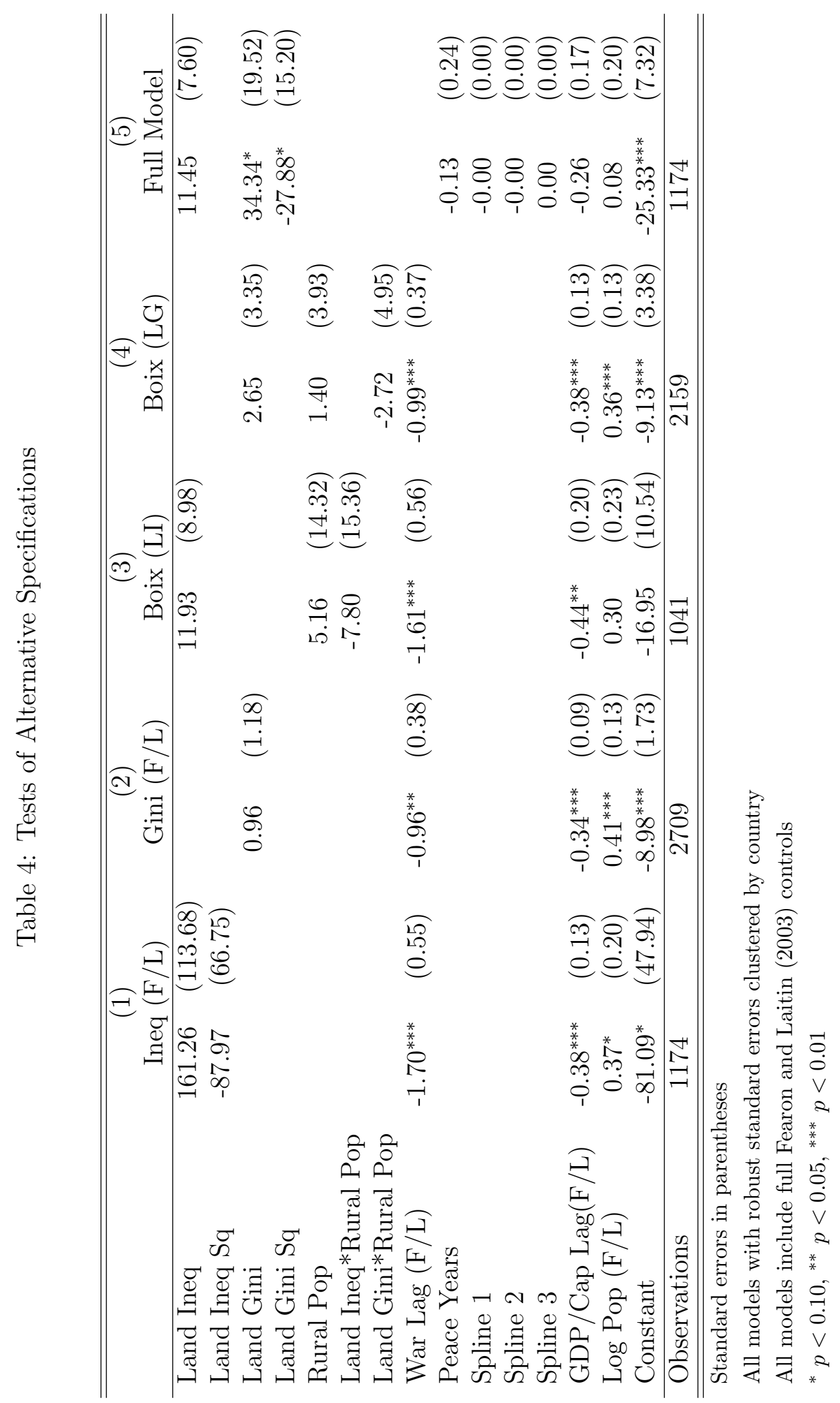




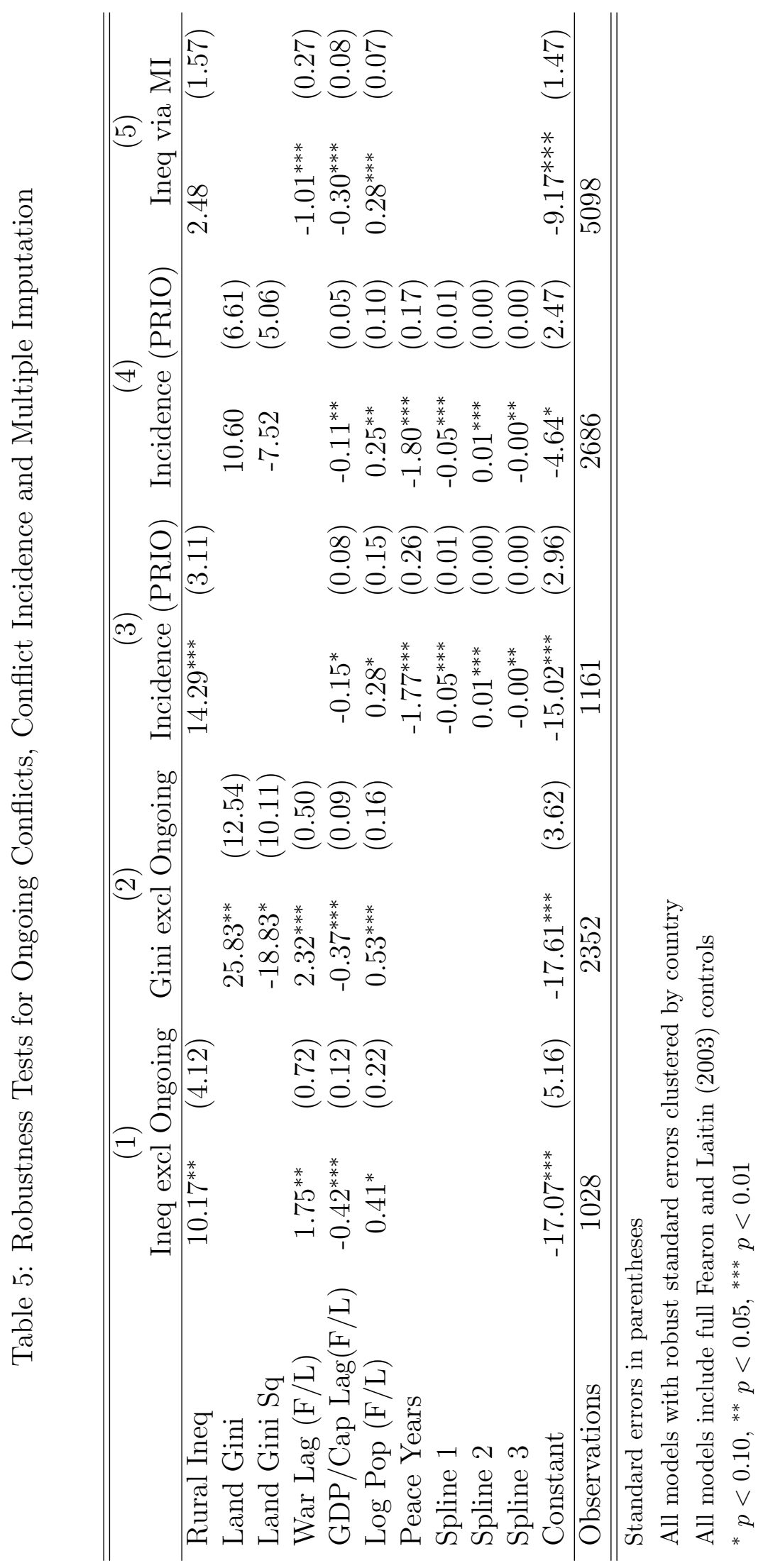


Table 6: List of Countries in Land Gini Models

$\begin{array}{lclclc}\text { Country } & \text { Obs. } & \text { Country } & \text { Obs. } & \text { Country } & \text { Obs. } \\ \text { ARGENTINA } & 29 & \text { HAITI } & 1 & \text { NIGERIA } & 1 \\ \text { AUSTRALIA } & 41 & \text { HONDURAS } & 30 & \text { NORWAY } & 51 \\ \text { AUSTRIA } & 45 & \text { HUNGARY } & 31 & \text { PAKISTAN } & 40 \\ \text { BANGLADESH } & 23 & \text { INDIA } & 43 & \text { PANAMA } & 50 \\ \text { BELGIUM } & 50 & \text { INDONESIA } & 31 & \text { PARAGUAY } & 31 \\ \text { BHUTAN } & 1 & \text { IRAN } & 1 & \text { PERU } & 34 \\ \text { BOLIVIA } & 12 & \text { IRAQ } & 31 & \text { PHILIPPINES } & 44 \\ \text { BOTSWANA } & 23 & \text { IRELAND } & 50 & \text { POLAND } & 40 \\ \text { BRAZIL } & 47 & \text { ISRAEL } & 32 & \text { PORTUGAL } & 50 \\ \text { BURKINA FASO } & 1 & \text { ITALY } & 40 & \text { RWANDA } & 1 \\ \text { BURMA } & 4 & \text { IVORY COAST } & 2 & \text { SAUDI ARABIA } & 1 \\ \text { CAMEROON } & 13 & \text { JAMAICA } & 16 & \text { SENEGAL } & 38 \\ \text { CANADA } & 41 & \text { JAPAN } & 43 & \text { SIERRA LEONE } & 15 \\ \text { CHILE } & 33 & \text { JORDAN } & 33 & \text { SOUTH AFRICA } & 1 \\ \text { CHINA } & 1 & \text { KENYA } & 15 & \text { SPAIN } & 30 \\ \text { COLOMBIA } & 46 & \text { KOREA S } & 30 & \text { SRI LANKA } & 39 \\ \text { COSTA RICA } & 35 & \text { KUWAIT } & 1 & \text { SUDAN } & 1 \\ \text { CYPRUS } & 18 & \text { LAOS } & 1 & \text { SWAZILAND } & 1 \\ \text { CZECHOSLOVAKIA } & 42 & \text { LEBANON } & 30 & \text { SWEDEN } & 49 \\ \text { DEM. REP. CONGO } & 21 & \text { LESOTHO } & 23 & \text { SWITZERLAND } & 22 \\ \text { DENMARK } & 51 & \text { LIBERIA } & 1 & \text { SYRIA } & 1 \\ \text { DOMINICAN REP. } & 46 & \text { LIBYA } & 1 & \text { TAIWAN } & 16 \\ \text { ECUADOR } & 45 & \text { MADAGASCAR } & 19 & \text { TANZANIA } & 10 \\ \text { EGYPT } & 40 & \text { MALAWI } & 25 & \text { THAILAND } & 31 \\ \text { EL SALVADOR } & 36 & \text { MALAYSIA } & 18 & \text { TOGO } & 22 \\ \text { ETHIOPIA } & 23 & \text { MAURITANIA } & 2 & \text { TUNISIA } & 35 \\ \text { FIJI } & 20 & \text { MEXICO } & 21 & \text { TURKEY } & 48 \\ \text { FINLAND } & 50 & \text { MOROCCO } & 15 & \text { UGANDA } & 27 \\ \text { FRANCE } & 37 & \text { MOZAMBIQUE } & 1 & \text { UK } & 50 \\ \text { GAMBIA } & 1 & \text { NAMIBIA } & 1 & \text { URUGUAY } & 49 \\ \text { GERMANY FED. REP. } & 36 & \text { NEPAL } & 28 & \text { USA } & 50 \\ \text { GHANA } & 15 & \text { NETHERLANDS } & 50 & \text { VENEZUELA } & 37 \\ \text { GREECE } & 50 & \text { NEW ZEALAND } & 31 & \text { VIETNAM } & 28 \\ \text { GUATEMALA } & 30 & \text { NICARAGUA } & 40 & \text { ZAMBIA } & 11 \\ \text { GUYANA } & 11 & \text { NIGER } & 1 & \text { Total } & 2709\end{array}$

